\title{
MODEL PENGUATAN PESAN DAMAI ALA WAHID FOUNDATION BAGI PENDIDIKAN KARAKTER PEMUDA MUSLIM JAKARTA PUSAT
}

\author{
Usman Sutisna \\ Program Studi Teknik Informatika, Universitas Indraprasta PGRI \\ Email: usmansutisna09@gmail.com
}

\begin{abstract}
Abstrak
Penelitian ini memiliki tujuan untuk menganalisa konsep perdamaian Wahid Foundation serta mengungkap penerapan dari konsep perdamaian K.H.Abdurrahman Wahid bagi para pemuda. Penelitian ini menggunakan teori Ursula Martius Franklin dan teori hukum logika biner tentang perdamaian. Penelitian ini dilakukan sejak bulan September 2018 sampai Juni 2019. Metode yang digunakan adalah metode penelitian deskriptif kualitatif dengan pengumpulan data melalui observasi lapangan, dokumentasi, studi literatur, dan wawancara mendalam (in deep-interview). Teknik analisa data dengan menggunakan tahapan reduksi, lalu menyajikan dan memperoleh kesimpulan. Hasil yang diperoleh dari penelitian ini adalah konsep perdamaian Wahid Foundation yaitu sikap atau kegiatankegiatan yang mendorong terciptanya kedamaian, toleransi dan penghargaan terhadap perbedaan. Sikap toleransi yang dimaksud di antaranya adalah menerima keberadaan orang atau penganut agama lain yang berbeda diterapkan melalui sikap menghargai sesama manusia, wujud dari toleransi tersebut adalah sikap menghargai pluralitas, menghargai pendapat, sikap keterbukaan terhadap perbedaan, membantu dan membela serta menghargai orang-orang yang tertindas atau mendapat perlakuan yang tidak adil, serta menjunjung tinggi persaudaraan sesama manusia. Dengan demikian pemuda dilatih untuk berpikir kritis, terbuka, egaliter, bijak dan kreatif serta mampu menempatkan diri ketika dihadapkan pada situasi yang mengharuskan sikap toleransi diterapkan.
\end{abstract}

Kata Kunci : Penguatan, Pesan Damai, Pemuda, Wahid Foundation

\begin{abstract}
This study aims to analyze the peace concept of the Wahid Foundation and to analyze the application of the peace concept of $K$. H. Abdurrahman Wahid for youth. This research uses Ursula Martius Franklin's theory and binary logic law theory about peace. The method used is a qualitative research method with data collection through field observations, documentation, literature study, and interviews. The results obtained from this study were the Wahid Foundation peace concept, namely tolerance and respect for differences. Tolerance is characterized by accepting the existence of people or followers of different religions accompanied by respect for fellow human beings, the manifestation of this tolerance is an attitude of respect for plurality, respect for opinions. , an attitude of openness to differences, helping and defending as well as respecting people who are oppressed or treated unfairly, and upholding human brotherhood. Youth can also use some of the Wahid Foundation models in implementing this concept in the school environment through the peaceful school program, namely by means of dialogue, discussion, and simulation. Thus youth are trained to think critically, openly, and creatively and be able to position themselves when faced with situations that require tolerance to be applied.
\end{abstract}

Key Words : Strengthening the Message of Peace, Youth, Wahid Foundation

\section{PENDAHULUAN}

Sebagaimana penelitian terdahulu hasil karya Agus Suliantono yang berjudul "Perdamaian Dalam Perspektif Al-Qur'an (Kajian Atas Penafsiran Mufasir Nusantara). Penelitian tersebut bertujuan untuk membangkitkan kesadaran masyarakat dalam interaksi kehidupan sehari-hari. Sekaligus mengaplikasikan sikap saling menghormati dan menghargai dalam dinamika kehidupan untuk mencapai ketenangan dan rasa damai dalam hati [1]. 
Pendidikan tentang konsep damai dan perdamaian telah ada di dalam Al-Qur'an lebih dari 14 abad yang lalu. Terdapat 12 ayat di dalam Al-Qur'an yang mengandung unsur damai dan devariasinya. Ayat-ayat tersebut adalah Q.S. Al-Baqarah [2]: 182; Q.S. An-Nisá' [4]: 114 \& 128; Q.S.A1Anfal [8]: 61; Q.S.AlQashash [28]: 19; Q.S. Muhammad [47]: 35; dan Q.S.AlHujurat [49]: 9-10. Bahkan bila dikaji melalui pencarian dengan kata kunci é As-Salám dan devariasinya, akan muncul 47 ayat lain dengan kandungan nilai damai yang terselip di dalam AlQur'an [2].

Dalam realita kehidupan bermasyarakat, sering kita jumpai berbagai tindak kekerasan, radikalisme dan intoleransi yang terjadi, baik di tingkat daerah maupun sampai level nasional. Kekerasan dan intoleransi ini umumnya terjadi di wilayah-wilayah yang masyarakatnya dalam kondisi ekonomi lemah, rendah pendidikan, dan minim informasi, yang memudahkan terjadinya provokasi sehingga tercipta tindakan diskriminasi. Bahkan tidak hanya di wilayah yang memiliki keterbatasan saja, tapi di Jakarta sendiri sangat banyak tindak kekerasan serta perilaku intoleransi yang terjadi. Hal tersebut tampaknya masih menjadi ancaman mulai pada tahun 2012 hingga memasuki tahun 2019.

Pemikiran radikalisme di kalangan umat Islam sering disandarkan dengan paham keagamaan yang sebenarnya tidak bisa dibenarkan. Pemahaman seperti ini sebenarnya tidak disebabkan oleh satu faktor yang berdiri sendiri. Faktor sosial, ekonomi, lingkungan, politik bahkan pendidikan pun ikut andil dalam mempengaruhi radikalisme agama. Namun demikian, radikalisme agama cenderung sering digerakkan oleh pemahaman keagamaan yang sempit, perasaan tertekan, terhegemoni, tidak aman secara psikososial, serta ketidakadilan lokal dan global [3].

Penelitian The Wahid Institute menyebutkan bahwa hampir sepanjang tahun 2018 telah terjadi 192 kasus pelanggaran kebebasan beragama dan berkeyakinan. Kasus ini melibatkan diantaranya 138 aktor negara dan 148 aktor non-negara. Terlebih dari beberapa kasus yang terjadi kelompok Muslim menempati posisi jumlah tertinggi sebagai pelaku pelanggaran dan intoleransi beragama. Hasil penelitian tersebut tentu dapat menciderai identitas Islam sebagai agama yang toleran dan menghargai hak beragama seseorang di Indonesia [4].

Dari berbagai macam tindak kekerasan dan intoleransi di atas, penulis melihat harus adanya upaya penanganan serius untuk menanggulangi masalah tersebut, dengan mencoba memberikan hal-hal yang mengusung pesan perdamaian dengan landasan program yang dimiliki Wahid Foundation. Seyogyanya Islam dengan kata As-Salam secara konsep akan mampu melahirkan suatu kesadaran akan pentingnya suatu perdamaian bukan malah yang terjadi sebaliknya yakni perpecahan, diskriminasi dan intoleransi [5].

Dalam Islam, perdamaian merupakan kunci pokok dalam menjalin hubungan antar umat manusia, sedangkan perang dan pertikaian adalah sumber malapetaka yang berdampak pada kerusakan sosial. Agama Islam sangat mengutamakan keselamatan dan perdamaian, juga menyeru kepada umat manusia agar selalu hidup rukun dan damai dengan tidak mengikuti hawa nafsu dan godaan Syaitan. Perdamaian berasal dari kata damai yang dalam Kamus Besar Bahasa Indonesia diartikan sebagai tidak ada peperangan, tidak ada kerusuhan, aman dan rukun [6]. 
Kendati demikan, dalam hukum logika biner juga disebutkan bahwa: keberadaan atau ketiadaan salah satu merupakan keberadaan sekaligus ketiadaan yang ada. Damai tidak akan tercipta jika konflik tidak ada. Damai menjadi ada karena adanya konflik. Ketika damai dinegasikan, hadirlah konflik, dan jika konflik dinegasikan maka hadirlah damai. Keduanya akan selalu hadir bersama seperti dua sisi mata uang [7].

Konsep perdamaian perspektif K.H. Abdurrahman Wahid adalah toleransi dan pengakuan terhadap perbedaan. Menurut beliau: Toleransi tidak hanya sekedar sikap hidup berdampingan secara damai dalam suasana saling menghormati dan menghargai, tetapi juga disertai kesediaan menerima penganut agama lain sebagai saudara sesama manusia [8].

Secara umum istilah toleransi memiliki pengertian sikap terbuka, lapang dada, suka rela dan lemah lembut. Unesco mengartikan toleransi dengan kondisi sikap saling menghormati, saling menerima, saling menghargai di tengah keragaman budaya, kebebasan berekspresi dan karakter manusia. Toleransi harus didukung oleh cakrawala pengetahuan yang luas, bersikap terbuka, dialog, kebebasan berpikir dan beragama. Singkat kata toleransi setara dengan sikap positif, dan menghargai orang lain dalam rangka menggunakan kebebasan asasi sebagai manusia [9].

Sebagai generasi penerus bangsa, kaum muda menjadi sangat penting. Kaum muda merupakan masa depan sebuah bangsa yang ingin maju. Kaum muda tidak bisa dituduh sebagai kelompok yang mengacaukan, tetapi mereka adalah kelompok masyarakat yang bergerak dan terus mencari formulasi posititf. Mereka kaum muda tidak bisa ditempatkan sebagai entitas yang selalu dalam "kesesatan pikir" dan kesesatan tindakan atas nama agama/Tuhan [10].

Pemuda adalah individu yang secara fisik sedang mengalami perkembangan dan secara psikis sedang mengalami perkembangan emosional, sehingga pemuda merupakan sumber daya manusia Pembangunan baik saat ini maupun nanti yang akan menggantikan generasi sebelumnya. Pemuda sebagai individu dengan karakter yang dinamis, bahkan bergejolak dan optimis namun belum memiliki pengendalian emosi yang stabil.

Pemuda berhadapan dengan masa perubahan sosial maupun kultural. Terdapat banyak pengertian tentang pemuda, baik definisi secara fisik ataupun psikis tentang siapa figur yang pantas disebut pemuda serta apakah pemuda selalu diasosiasikan dengan semangat dan usia.

Pemuda adalah individu dengan karakter yang dinamis, bahkan bergejolak dan optimis namun belum memiliki pengendalian emosi yang stabil. Pemuda menghadapi masa perubahan sosial maupun kultural [11].

Karakter yang baik berkaitan dengan pengetahuan yang baik (knowing the good), mencintai yang baik (loving the good), dan perilaku positif (acting the good). Ketiga ideal ini satu sama lain sangat berkaitan. Seseorang lahir dalam keadaan bodoh, dorongan-dorongan primitif yang ada dalam dirinya kemungkinan dapat memerintahkan atau menguasai akal sehatnya. Maka efek yang mengiringi pola pengasuhan dan pendidikan seseorang akan dapat mengarahkan kecenderungan, perasaan, dan nafsu besar menjadi beriringan secara harmoni atas bimbingan akal dan juga ajaran agama [12]. 
Pembentukan karakter tentunya harus dimulai dari pribadi/ diri sendiri, dalam keluarga (sebagai sel inti bangsa) terutama orang tua sebagai pendidiknya. Pembentukan karakter merupakan "mega proyek" yang sungguh sulit, membutuhkan usaha, dan energi yang tidak sedikit. Dibutuhkan komitmen, ketekunan, keuleten, proses, metode, waktu, dan yang terpenting adalah keteladanan. Masalah keteladanan ini menjadi sesuatu yang sulit pada masa kini dan tentu sangat dibutuhkan dalam sebuah bangsa yang sedang mengalami krisis kepercayaan multidimensional [13].

Melihat kenyataan tersebut, penulis meyakini besarnya potensi Wahid Foundation untuk membentuk dan meningkatkan toleransi masyarakat dan para pemuda khususnya di beberapa SMA di Jakarta Pusat agar dapat menjunjung tinggi arti perdamaian dan menjaga situasi damai, sikap toleransi dan penghargaan terhadap perbedaan.

\section{METODE}

Jenis penelitian kualitatif deskriptif. Dimana peneliti sebagai instrumen kunci akan melihat dan menganalisis mengenai data yang didapat guna menjawab permasalahan yang ada di masyarakat lalu berusaha mendeskripsikan peristiwa dan kejadian yang menjadi objek perhatian tanpa memberikan perlakukan khusus terhadap peristiwa tersebut. Variabel yang diteliti bisa tunggal (satu variabel) bisa juga banyak variabel [14].

Sumber data dalam penelitian ini terbagi menjadi dua sumber data yakni data utama dan data pelengkap. Data utama yaitu hasil observasi, wawancara dengan pimpinan Wahid Foundation, wawancara dengan pemuda dan kuisioner sedangkan sumber data pelengkap antara lain: buku-buku, jurnal penelitian, artikel berita dan lain sebagainya.
Penelitian ini menggunakan metode penelitian kualitatif yang menggunakan teknik pengamatan, teknik wawancara serta studi dokumentasi sebagai teknik pengumpulan data [15]. Teknik pengamatan atau observasi, yakni melihat pelaksanaan model Penguatan pesan damai ala Wahid Foundation, teknik wawancara digunakan untuk memperoleh informasi mengenai pesan damai Wahid Foundation, kendala dalam pelaksanaan dan informasi terkait lainnya. Studi dokumentasi digunakan untuk memperoleh data mengenai pelaksanaan pesan damai ala Wahid Foundation kepada Pemuda Muslim Jakarta Pusat.

Setelah data terkumpul, kemudian peneliti menganalisis data dengan teknik analisis secara deskriptif-kualitatif. Tujuan deskriptif ini adalah untuk mendeskripsikan, gambaran atau lukisan secara sistematis, faktual, akurat mengenai fakta-fakta serta berhubungan dengan fenomena yang diselidiki.

Adapun lokasi penelitian sebagai tempat untuk melakukan observasi yakni di Wahid Foundation yang beralamat Jl. Taman Amir Hamzah No.8 RT 01/RW 04 Menteng Jakarta Pusat dan SMK Negeri 31 Jakarta pada bulan September 2018 - Juni 2019

\section{HASIL DAN PEMBAHASAN Konsep Penguatan Pesan Damai Wahid Foundation}

Wahid Foundation dibangun atau dibentuk untuk memperjuangkan visi misi Gus Dur. Dari pondasi tersebut lembaga ini dibangun. Secara khusus sebagaimana take line dari lembaga ini adalah seading peaceful Islam artinya menyemai islam yang damai. Lalu pondasi-pondasi damai itu dari berasal agama, nilai-nilai konstitusional, nilai-nilai kebangsaan dan keindonesiaan. Konsep-konsep yang mereka pegang itu secara umum ada di 
buku Narasi Damai. Dalam buku tersebut dijelaskan bahwa Keindonesiaan itu masuk ke dalam lokalitas atau cenderung dekat ke NU.

"Pertama, secara teknis pola atau model Wahid Foundation itu turun kepada kegiatan-kegiatan yang multikultural, budaya, heterogen masyarakat. Kita juga mempunyai konsentrasi khusus dalam keterlibatan agama-agama, jadi tidak hanya islam semacam dialog-dialog antar agama. Cirinya dari pesan damai masing-masing agama dan ke Indonesiaan. Kedua, melibatkan agama-agama dalam upaya damai ini, diajak dialog bersama. Ketiga, diturunkan lagi ke para pemuda, bagaimana narasi-narasi yang besar tadi di tekniskan dan disharing kepada pemudapemuda".

Menurut Wahid Foundation polanya yakni menggunakam media-media yang sangat akrab di lingkungan anak-anak muda, seperti:

1. Menggunakan pendekatan media sosial (teknologi);

2. Wahid Foundation itu mengadakan pendekatan yang fun (ceria) didekati melalui board game (permainanpermainan untuk anak muda);

3. Menggunakan eksplorasi daya imajinasi dengan komik atau kartun. (komik gus dur);

4. Kami membimbing para pemuda untuk menyebarkan konten-konten pesan damai melalui media teknologi;

5. Melalui hasil-hasil riset, karena semua yang dilakukan Wahid Foundation itu basisnya adalah dari hasil riset, survei dan mengadakan pendekatan kepada lingkungan anak-anak muda. Seperti guru-guru sekolah (didampingi oleh Wahid Foundation), orang tua murid (dirangkul) agar mereka semua terlibat dalam kampanye damai di wilayah mereka masing-masing;
6. Mengadakan pelatihan menulis, contoh karya anak muda yang berjudul "Antologi Kisah Orang Muda untuk Perdamaian";

7. Critical thinking adalah salah satu model penguatan Wahid Foundation agar para pemuda diajak untuk berpikir kritis, sehingga tidak secara mentah menerima informasi yang mereka dapat di Medsos dan lain-lain.

\section{Program-Program Pesan Damai}

Beberapa program pesan damai bagi para pemuda atau remaja di sekolah di antaranya adalah: rohis, pengawasan paham radikal, dan pengembangan budaya damai di sekolah.

\section{Rohis}

Program sekolah damai juga adalah perpaduan dari Pemahaman Konsep damai Wahid Foundation dengan program rohis yang ada di sekolah, karena program ini merupakan penguatan materi kegiatan yang sudah ada dan biasa dilakukan dalam kegiatan rohis. Selama ini program dan materi rohis diserahkan sepenuhnya kepada mentor, yang berbekal kepercayaan saja. Guru Pembina rohis kadang tidak melakukan pengawasan (controlling) terhadap materi yang disampaikan dalam kegiatan rohis (Hasil Observasi).

Dalam sekolah yang dinaungi Wahid Foundation yang ada di Jakarta yakni SMK Negeri 12 Jakarta, SMK Negeri 4 Jakarta, SMA Negeri 40 Jakarta, SMA Negeri 72 Jakarta dan SMK Negeri 31 Jakarta. Pihak Wahid memberikan panduan atau acuan materi yang harus disampaikan dalam kegiatan pemanduan (mentoring) rohis, diharapkan materi bisa lebih terukur dan terpantau serta dapat dilakukan pengawasan oleh dewan Pembina (Hasil Observasi). Berikut adalah materi rohis yang harus diperhatikan oleh Pembina rohis dan mentor. 
Tabel 1. Materi Rohis

\begin{tabular}{|c|c|c|}
\hline No & Materi & Keterangan \\
\hline 1. & Kajian Keagamaan & $\begin{array}{l}\text { Pemahaman Keagamaan yang moderat; Memahami bahaya } \\
\text { terorisme; SIrah Nabawiyah, Sirah Sahabat. }\end{array}$ \\
\hline 2. & Kajian Tafsir Alquran & $\begin{array}{l}\text { Memahami makna jihad dan ayat-ayat perdamaian dalam } \\
\text { Al-Qur'an. }\end{array}$ \\
\hline 3. & Wawasan Kebangsaan & Penguatan Pancasila, NKRI, dan Nasionalisme. \\
\hline 4. & Kampanye Damai & Mading, Pamflet, bakti sosial. \\
\hline 5. & Kajian Fiqh & Ibadah, muamalah, fiqih sosial. \\
\hline 6. & Kepemimpinan & Kepemimpinan dalam ibadah dan pemerintah. \\
\hline
\end{tabular}

\section{Pengawasan Paham Radikal}

Jika terjadi adanya indikasi siswa yang telah terkena paham radikal, sekolah bersama orang tua melakukan pengawasan ketat terhadap setiap aktivitas keagamaan yang dilakukan siswa, baik di dalam sekolah maupun di luar. Di sekolah, guru agama bersama dengan guru mata pelajaran lain melakukan pengawasan secara rutin terhadap semua kegiatan siswa. Sekaligus pendalaman informasi terkait asal muasal masuknya paham tersebut (hasil observasi).

Berikut deskripsi pengawasan yang harus dilakukan. Pertama, Pengawasan di Lingkungan Sekolah. Pengawasan di lingkungan sekolah dilakukan oleh guru agama, bekerjasama dengan guru BK dan wakil kepala sekolah bidang kesiswaan, polisi, wali kelas, guru mata pelajaran, komite sekolah, serta warga sekolah. Pengawasan dilakukan dengan cara mengawasi perilaku siswa ketika mengikuti jam pelajaran. Agar kegiatan tersebut lebih efektif, maka perlu melibatkan kementerian agama serta dinas pendidikan dan olahraga setempat.

Kedua, Pengawasan di Lingkungan Keluarga. Keluarga merupakan salah satu elemen penting dalam mewujudkan terciptanya pendidikan yang lebih baik bagi anak. Oleh karena itu, penting bagi orang tua mengetahui perkembangan anaknya dalam memahami prinsip dasar terjerumus pada paham radikal. Salah satu upaya yang harus dilakukan orang tua adalah memantau kegiatan anak di luar rumah, dengan siapa mengaji, dan materi apa saja yang menjadi objek kajiannya.

Ketiga, Pengawasan di Masyarakat. Pengawasan kegiatan siswa di lingkungan masyarakat harus juga dilakukan agar terjadi sinergi antara pengawasan pada sekolah dan di lingkungan keluarga. Salah satu bentuk pengawasan yang dapat dilakukan antara lain dengan cara melibatkan teman dekat untuk memberikan laporan kepada guru agama atau bimbingan konseling (BK), tentang kegiatan yang dilakukan siswa tersebut di luar rumah.

Dengan pantauan teman dekat tersebut, akan memudahkan pihak sekolah dalam mencarikan jalan keluar atau pendekatan terhadap permasalahan paham keagamaan yang ditakuti oleh siswa tersebut. Agar kegiatan pengawasan dapat berjalan efektif, maka perlu melibatkan tokoh masyarakat, tokoh agama, serta elemen lain yang dapat mendukung kegiatan pengawasan tersebut.

\section{Pengembangan Budaya Damai di Sekolah}

Pengembangan budaya damai di sekolah yang dinaungi oleh Wahid Foundation ini dilakukan dengan tujuan penguatan spirit nasionalisme dan penghargaan terhadap perbedaan. Penguatan nasionalisme dilakukan melalui upacara rutin hari Senin dan hari besar nasional, pemutaran lagulagu nasional pada jam istirahat, 
memahami kekayaan budaya, dan kekayaan Indonesia, serta berbagai kegiatan lain yang bisa dijelajahi oleh pihak sekolah sesuai tema dan isu aktual yang akan dirancang. Kegiatan penghargaan terhadap perbedaan dilakukan dengan cara memberikan kesempatan pada siswa pemeluk agama non-Islam untuk beribadah sesuai agama dan keyakinannya masing-masing, melakukan kegiatan bersama dalam bakti sosial, membersihkan lingkungan sekolah, program bersama (senyum, salam, sapa, sopan, santun) rutin seklah, satu hari merayakan perbedaan (one day different), dan program lain yang bisa dikreasikan oleh sekolah dan siswa.

Kegiatan penguatan nasionalisme dan penghargaan terhadap perbedaan dilakukan melalui pembiasaan (hidden curriculum). Selain itu, dua program tersebut juga disatukan dalam kegiatan pembelajaran di kelas. Penguatan nilai-nilai nasionalisme dan penghargaan terhadap perbedaan harus nampak dan terstruktur dalam setiap kegiatan belajar-mengajar di kelas. Seperti sebaran anggota kelompok yang heterogen dalam tugas diskusi, kesepakatan bersama terkait nilai-nilai kebangsaan yang dibuat dalam kelas, yel-yel kelas berkaitan nasionalisme dan penghargaan terhadap perbedaan, dan lain sebagainya.

\section{SIMPULAN}

Paparan panjang mengenai model penguatan pesan damai di atas, dapat disimpulkan sebagai berikut: Pertama, Konsep Penguatan Wahid Foundation mencoba mengembangkan berbagai kegiatan-kegiatan yang berkaitan dengan perdamaian sesuai kondisi masyarakat dalam upaya memajukan pengembangan toleransi, keberagaman dalam masyarakat Indonesia, meningkatkan kesejahteraan masyarakat miskin, membangun demokrasi dan keadilan fundamental, dan memperluas nilai-nilai perdamaian dan non-kekerasan di Indonesia dan di seluruh dunia.
Kedua, Program-program ini juga dikembangkan dengan mendorong para pemuda untuk mengetahui, mempelajari dan memahami apa arti perdamaian melalui program sekolah damai yang dinaungi oleh Wahid Foundation. Program ini menyasar sejumlah kelompok sasaran strategis seperti Pemuda yang masih duduk ditingkat sekolah menengah atas, kepala sekolah, guru agama dan orang tua murid.

Ketiga, Implementasi dari penguatan pesan damai melalui sekolah damai untuk menangkal paham radikal teroris dan intoleransi kaum pemuda di sekolah perlu dilakukan bersamaan dengan pengembangan budaya damai dan penghargaan terhadap perbedaan, menumbuhkan keberagaman di sekolah dengan mengedepankan penghargaan dan penghormatan terhadap perbedaan suku, agama, dan pendapat yang ada di sekolah dengan cara memasukkan program sekolah damai di dalam kegiatan Rohis.

\section{DAFTAR PUSTAKA}

[1] A. Suliantono, "Perdamaian dalam Perspektif Alquran: Kajian Atas Penafsiran Mufasir Nusantara," Jakarta, 2019.

[2] N. Hidayat, "Nilai-nilai Ajaran Islam tentang Perdamaian (Kajian antara Teori dan Praktek)," Apl. J. Apl. Ilmu-ilmu Agama, vol. 17, no. 1, pp. 15-24, 2017.

[3] A. S. Adi dan N. A. K. Wardani, "Peran Pimpinan Cabang Gerakan Pemuda Ansor Sidoarjo dalam Meningkatkan Nasionalisme untuk Menangkal Radikalisme," Kaji. Moral dan Kewarganegaraan, vol. 7, no. 1, pp. 301-315, 2019.

[4] Gusnanda dan Nuraini, "Menimbang Urgensi Ukhuwah Wathaniyah dalam Kasus Intoleransi Beragama di Indonesia," FUADUNA J. Kaji. Keagamaan dan Kemasyarakatan, vol. 04, no. 01, pp. 1-14, 2020. 
[5] E. T. Taufik, D. F. Humaira, J. L. Adisucipto, dan D. I. Yogyakarta, "Membumikan Pesan Damai dalam Al-Quran," J. An-Nida, vol. 12, no. 2, 2020.

[6] Tim Penyusun. Kamus Bahasa Indonesia. Jakarta: Pusat Bahasa, 2008.

[7] I. Taufiq. Al-Qur'an Bukan Kitab Teror. Yogyakarta: PT Bentang Pustaka, 2016.

[8] A. Nurcholis. Peace Education \& Pendidikan Perdamaian Gus Dur. Jakarta: Elex Media Komputindo, 2015.

[9] Casram, "Membangun Sikap Toleransi Beragama," Wawasan J. Ilm. Agama dan Sos. Budaya, vol. 1, no. March, pp. 187-198, 2016.

[10] Z. Qodir, "Kaum Muda, Intoleransi, dan Radikalisme Agama," J. Stud. PEMUDA, vol. 5, no. 1, pp. 429445, 2016.

[11] T. Abdullah. Pemuda dan Perubahan Sosial. Jakarta: LP3ES, 1994.

[12] A. Sudrajat, "Mengapa pendidikan karakter?," J. Pendidik. Karakter, vol. 1, no. 1, pp. 47-58, 2011.

[13] H. Ainissyifa, "Pendidikan Karakter dalam Perspektif Pendidikan Islam," J. Pendidik. Univ. GARUT, pp. 1-26, 2012.

[14] Direktorat Tenaga Kependidikan, Pendekatan, jenis dan metode penelitian kependidikan. Jakarta: Departemen Pendidikan Nasional, 2008.

[15] Suryana. Metodologi Penelitian: Model Praksis Penelitian Kuantitatif dan Kualitatif. Bandung: LPI, 2010. 